\title{
Identification of Vitis vinifera L. grape berry skin color mutants and polyphenolic profile
}

\author{
Vanessa Ferreira ${ }^{\mathrm{a}, \mathrm{b}}$, Fátima Fernandes ${ }^{\mathrm{c}}$, Olinda Pinto-Carnide ${ }^{\mathrm{d}}$, Patrícia Valentão ${ }^{\mathrm{c}}$, Virgílio Falco ${ }^{\mathrm{e}}$, \\ Juan Pedro Martín ${ }^{\mathrm{f}}$, Jesús María Ortiz ${ }^{\mathrm{f}}$, Rosa Arroyo-García ${ }^{\mathrm{b}}$, Paula B. Andrade ${ }^{\mathrm{c}}$, Isaura Castro ${ }^{\mathrm{a}, *}$ \\ ${ }^{a}$ Centro de Investigação e de Tecnologias Agro-Ambientais e Biológicas (CITAB), Universidade de Trás-os-Montes e Alto Douro, 5000-801 Vila Real, Portugal

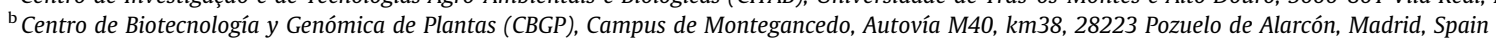

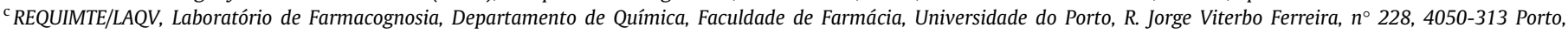 \\ Portugal \\ ${ }^{\mathrm{d}}$ Universidade de Trás-os-Montes e Alto Douro, 5000-801 Vila Real, Portugal \\ e Centro de Química de Vila Real (CQ-VR), Universidade de Trás-os-Montes e Alto Douro, 5000-801 Vila Real, Portugal \\ ${ }^{\mathrm{f}}$ Dpto. de Biotecnología-Biología Vegetal, Escuela Técnica Superior de Ingenieros Agrónomos, Universidad Politécnica de Madrid, Ciudad Universitária s/n, 28040 Madrid, Spain
}

\section{A R T I C L E I N F O}

\section{Article history:}

Received 11 May 2015

Received in revised form 27 July 2015

Accepted 28 July 2015

Available online 1 August 2015

Chemical compounds studied in this article:

Gallic acid (PubChem CID: 370)

Caftaric acid (PubChem CID: 6440397)

Catechin (PubChem CID: 73160)

Epigallocatechin gallate (PubChem CID: 65064)

Quercetin-3-O-galactoside (PubChem CID:

5281643)

Quercetin-3-O-glucoside (PubChem CID: 25203368)

Malvidin-3-O-glucoside (PubChem CID:

443652)

Peonidin-3-0-p-coumaroylglucoside

(PubChem CID: 44256849)

Malvidin-3-O-p-coumaroylglucoside

(PubChem CID: 44256988)

Resveratrol-3-O-glucoside (PubChem CID:

25579167)

Keywords:

Anthocyanins

Microsatellites

Non-colored phenolics

Skin color mutants

Vitis vinifera $\mathrm{L}$.

\begin{abstract}
A B S T R A C T
A germplasm set of twenty-five grapevine accessions, forming eleven groups of possible berry skin color mutants, were genotyped with twelve microsatellite loci, being eleven of them identified as true color mutants. The polyphenolic profiling of the confirmed mutant cultivars revealed a total of twenty-four polyphenols, comprising non-colored compounds (phenolic acids, flavan-3-ols, flavonols and a stilbene) and anthocyanins.

Results showed differences in the contribution of malvidin-3-O-glucoside to the characteristic Pinot Noir anthocyanins profile. Regarding the two Pique-Poul colored variants, the lighter variant was richer than the darker one in all classes of compounds, excepting anthocyanins. In Moscatel Galego Roxo the $\mathrm{F}^{\prime} \mathrm{H}$ pathway seems to be more active than $\mathrm{F}^{\prime}{ }^{\prime}{ }^{\prime} \mathrm{H}$, resulting in higher amounts of cyanidin, precursor of the cyanidin derivatives.

As far as we are aware, this is the first time that a relationship between the content of polyphenolic compounds is established in groups of grape berry skin color mutant cultivars.
\end{abstract}

(c) 2015 Elsevier Ltd. All rights reserved.

\section{Introduction}

Grapevine (Vitis vinifera L.) is one of the most cultivated fruit plants and an economically important crop worldwide. Grapes,

\footnotetext{
* Corresponding author.

E-mail address: icastro@utad.pt (I. Castro).
}

consumed either as fresh fruit or as products derived from them (wine, juice and others), are a rich source of polyphenolic compounds (Fraige, Pereira-Filho, \& Carrilho, 2014). These compounds are one of the main quality factors of grapes and wine, due to their contribution to wine color, oxidation reactions, interactions with proteins, aging behavior of wines and sensorial characteristics, such as bitterness and astringency (Figueiredo-González, 
Martínez-Carballo, et al., 2012). In red wines, the perception of astringency has been mainly attributed to proanthocyanidins, also known as condensed tannins, which are involved in copigmentation processes with the anthocyanins and the formation of new pigments, which contribute to the stability and definition of red wine color (Quijada-Morín et al., 2012).

In addition, polyphenols are confirmed to have a variety of effects on human health, such as anti-inflammatory, antimicrobial and anti-aging, and also to play a preventing role against cardiovascular diseases (Ivanova et al., 2011). They are considered to be the key compounds responsible for the antioxidant potential of grapes and wine (Burns et al., 2000).

Polyphenolic compounds are mainly present in skin and seeds of grape berries and can be classified in two groups, flavonoids and non-flavonoids, based on the primary chemical structures of hydroxybenzenes (Gómez Gallego, Gómez García-Carpintero, Sánchez-Palomo, Hermosín-Gutiérrez, \& González Viñas, 2011; Liang, Owens, Zhong, \& Cheng, 2011). The majority of the flavonoids found in grapes include flavan-3-ols, flavonols and anthocyanins, three structural classes divided according to the oxidation degree of their heterocyclic ring. Non-flavonoids are mainly hydroxycinnamic and hydroxybenzoic acids, stilbenes and volatile phenols (Figueiredo-González, Martínez-Carballo, et al., 2012; Liang et al., 2011; Teixeira, Eiras-Dias, Castellarin, \& Gerós, 2013).

Among these classes of polyphenolic compounds, hydroxycinnamic and hydroxybenzoic acids play critical roles in developing the bitterness and astringency properties of wine. The synthesis of hydroxycinnamic acids occurs mainly before verraison and they are commonly accumulated in berry skin and flesh of white and red varieties. Their concentration decreases with the increase of fruit size and dilution solutes during ripening. Particularly in white wines, hydroxycinnamic acids contribute to color browning under oxidation with non-phenolic molecules. Compared to the amount of hydroxycinnamic acids, hydroxybenzoic derivatives levels are commonly low in wine (Teixeira, Eiras-Dias, Castellarin, \& Gerós, 2013).

Anthocyanins are the most abundant polyphenolic compounds in colored grapes, being responsible for red, purple and blue pigmentation of the grape berries and, consequently, of the red wine. The second most abundant class of flavonoids is flavan-3-ols. In grape, flavan-3-ols exist as monomers or linked forming condensed tannins. Flavan-3-ols have a direct impact on the complexity of wine taste and mouthfeel, being responsible for bitterness of wine and also associated with astringency (Liang et al., 2011; Teixeira et al., 2013). Flavonols are found in grapes and wine as glycosides. Flavonols are yellow pigments that directly contribute to the color of white wines, being masked by anthocyanins in red wines. However, flavonols are also important cofactors for color enhancement, affecting red wine color by means of copigmentation (Castillo-Muñoz, Gómez-Alonso, García-Romero, \& Hermosín-Gut iérrez, 2010; Liang et al., 2011).

Because of the role of polyphenols in the overall quality and, therefore, the market value of grapes and grape products, there has been considerable interest and research in determining the composition and contents of polyphenolic compounds in grape cultivars (Liang et al., 2011) and wines, particularly by relating the polyphenolic content and profile with specific features, such as color, astringency and sweetness (Figueiredo-González, Cancho-Grande, \& Simal-Gándara, 2013; Figueiredo-González, Cancho-Grande, et al., 2014; Figueiredo-González, Regueiro, Cancho-Grande, \& Simal-Gándara, 2014; Quijada-Morín et al., 2012). Although polyphenolic compounds biosynthesis in $V$. vinifera $\mathrm{L}$. grapes is under genetic control and can be affected by several factors, as grape variety, ripening stage, climate, soil, light, place of growing and vine cultivation, the differences among grape cultivars are sometimes enough to make possible to use grape polyphenolic composition as a tool for cultivar authenticity and differentiation (Castillo-Muñoz et al., 2010).

Grape variety identification can be achieved by accurate genetic methods (Polymerase Chain Reaction - PCR), usually molecular markers. However, such methods are not currently available for grape berry color mutant cultivars discrimination. As so, the aim of this study was to provide data about the characteristic profiles of polyphenolic compounds of ripe grapes, by determining the compounds on a group of color and non-color related berried grapevine cultivars, derived from single varieties identified and selected by Simple Sequence Repeat (SSR) molecular markers.

\section{Materials and methods}

\subsection{Standards and reagents}

Acetic acid, acetonitrile, methanol ( $\mathrm{MeOH})$, ethyl acetate, formic acid and sodium hydroxide were purchased from Merck (Darmstadt, Germany) and hydrochloric acid from Pronalab (Lisboa, Portugal). The polyphenolic compounds used as reference were purchased from Sigma-Aldrich (Steinheim, Germany) (caftaric acid, gallic acid, p-coumaric acid, quercetin-3-O-glucoside, epigallocatechin gallate, resveratrol-3-O-glucoside and syringic acid) and Extrasynthése (Genay, France) (catechin, epigallocatechin, cyanidin-3-Oglucoside, delphinidin-3-O-glucoside, (-)-epicatechin, epicatechin gallate, isorhamnetin-3-O-glucoside, kaempferol-3-O-glucoside, malvidin-3-O-glucoside, peonidin-3-O-glucoside, quercetin-3-Ogalactoside, quercetin-3-O-rutinoside and syringetin-3-Oglucoside).

The water was treated in a Milli-Q water purification system (Millipore, Bedford, MA).

Solid-phase extraction (SPE) was performed with Chromabond C18 non-endcapped (NEC) columns ( $50 \mu \mathrm{m}$ particle size, $60^{\circ} \mathrm{A}$ porosity; $10 \mathrm{~g}$ sorbent mass $/ 70 \mathrm{~mL}$ reservoir volume) from Macherey-Nagel (Düren, Germany).

\subsection{Grape samples}

Twenty-five grapevine accessions of different varieties were harvested in 2011 in the same plot, in the experimental vineyard of the University of Trás-os-Montes and Alto Douro, Vila Real $\left(41^{\circ} 19^{\prime} \mathrm{N}, 7^{\circ} 44^{\prime} \mathrm{W}, 500 \mathrm{~m}\right.$ above mean sea level), Baixo Corgo sub-region of the Demarcated Douro Region, northern Portugal. The cultivation practices followed (spraying of crop protectants, weed control, shoot guiding) were the same for all vines. The mean annual temperature in the region was $13.3^{\circ} \mathrm{C}$; and total annual rainfall was $721 \mathrm{~mm}$ (IPMA, 2015).

Sampling was performed by picking young leaves and optimum ripeness berries randomly distributed throughout each plant. Samples represent a putative berry color mutant pool, which includes samples with similar designation, differing only in relation to the name of its skin berry color.

After harvest, the entire grapes were stored at $-20^{\circ} \mathrm{C}$ and freeze-dried in a Labconco Freezone 4.5 apparatus (Kansas City, MO, US). The lyophilized samples were then powdered in an appliance mill (model A327R1, Moulinex, Spain). The powdered material was kept in a desiccator, in the dark, until analysis.

Voucher specimens were deposited at Laboratório de Farmacognosia, Faculdade de Farmácia, Universidade do Porto, and at Laboratório de Marcadores Moleculares, University of Trás-os-Montes and Alto Douro under the following designations: AL092011_B (Alvarelhão), ALB092011_W (Alvarelhão Branco), B092011_B (Bastardo), BR092011_R (Bastardo Roxo), BB092011_W (Bastardo Branco), CB092011_W (Carrega Branco), CT092011_B (Carrega Tinto), MF092011_W (Malvasia Fina), 
MFR092011_R (Malvasia Fina Roxo), MR092011_W (Malvasia Rei), MRT092011_B (Malvasia Rei Tinto), MGB092011_W (Moscatel Galego Branco), MGR092011_R (Moscatel Galego Roxo), MGT092011_B (Moscatel Galego Tinto), M092011_B (Mourisco), MB092011_W (Mourisco Branco), PB092011_W (Pinot Blanc), PG092011_R (Pinot Gris), PN092011_B (Pinot Noir), PPG092011_R (Pique-Poul Gris), PPN092011_B (Pique-Poul Noir), TB092011_W (Touriga Branco), TT092011_B (Touriga Tinto), G092011_W (Gouveio), GR092011_R(Gouveio Roxo).

\subsection{DNA extraction and nuclear microsatellite amplification}

Accessions were genotyped by amplifying a set of twelve microsatellite markers, including the Organisation Internationale de la Vigne et du Vin (OIV) core set: VVS2, VVMD5, VVMD7, VVMD27, ssrVrZAG62, ssrVrZAG79, that correspond to OIV801 to OIV806 descriptors (OIV., 2009), established by the European Project GENRES\#81 for the identification of grapevine cultivars and part of the OIV 'Descriptor List for Grapevine Varieties and Vitis Species' along with VVMD28, VVMD32 (Bowers, Dangl, \& Meredith, 1999), VVIv37, VVIv67, VVIp31 (Merdinoglu et al., 2005) and VMC4f3 (Di Gaspero, Peterlunger, Testolin, Edwards, \& Cipriani, 2000).

Young leaves genomic DNA was extracted using DNeasy ${ }^{\circledR}$ Plant Mini Kit (QIAGEN, Düren, Germany) purification kit, according to the manufacturer's instructions. Extracted genomic DNA was quantified using a UV spectrometer (Nanodrop ${ }^{\circledR}$ ND-1000, Fisher Scientific, Wilmington, Delaware, USA), followed by quality check in a $1.0 \%$ agarose gel electrophoresis. Necessary dilutions were done (approximately $10 \mathrm{ng} / \mu \mathrm{L}$ ) and kept at $4{ }^{\circ} \mathrm{C}$ for further utilization.

Each $20 \mu \mathrm{L}$ PCR mixture contained $0.2 \mathrm{mM}$ of deoxynucleotide triphosphate (dNTP), $2 \mathrm{mM}$ of $\mathrm{MgCl}_{2}, 10 \mathrm{ng}$ of template DNA, various concentrations of primer and $1 \mathrm{U}$ of Taq DNA polymerase in the manufacturer's buffer. One primer of each pair was fluorescently labeled with 6-fluorescein amidite (FAM) (blue), tetrachlorofluorescein succinimidyl ester (TET) (green) or hexachlorofluorescein succinimidyl ester (HEX) (yellow). PCR amplifications were performed in a $\mathrm{T}-100^{\mathrm{TM}}$ Thermal Cycler (BIORAD). The program comprised an initial denaturation step $\left(95^{\circ} \mathrm{C} / 5 \mathrm{~min}\right)$, followed by 40 cycles of $94^{\circ} \mathrm{C} / 45 \mathrm{~s}, 50^{\circ} \mathrm{C} / 60 \mathrm{~s}$ and $72{ }^{\circ} \mathrm{C} / 90 \mathrm{~s}$.

Two multiplex PCRs were carried out with the OIV simple Sequence Repeats (SSR) core set, the first one involving VVS2, VVMD5 and VVMD7 (set A), and the second VVMD27, ssrVrZAG62 and ssrVrZAG79 (set B).

Set A multiplex reactions contained $0.2 \mu \mathrm{M}$ of VVS2, $0.5 \mu \mathrm{M}$ of VVMD5 and $0.25 \mu \mathrm{M}$ of the VVMD7 primer pairs. Set B reactions included $0.5 \mu \mathrm{M}$ of VVMD27 and of ssrVrZAG79, and $0.1 \mu \mathrm{M}$ of ssrVrZAG62 primer pairs. Individual reactions were performed with the remaining six primer pairs (VVMD28, VVMD32, VVIv37, VVIv67, VVIp31 and VMC4f3), with a primer concentration of $0.5 \mu \mathrm{M}$.

The amplicons were separated in $3 \%(\mathrm{w} / \mathrm{v})$ agarose gel electrophoresis in Tris-borate-EDTA (TBE) buffer, for $2 \mathrm{~h}$ at a constant voltage of $120 \mathrm{~V}$, followed by ethidium bromide staining to verify the existence of amplicons, and then by capillary electrophoresis (ABI PRISM model 310, PE Applied Biosystems, CA, USA). GENESCAN-350 TAMRA (PE Applied Biosystems, CA, USA) was included as internal sizing standard and labeled products were analyzed and sized using Peak Scanner V1.0 software (PE Applied Biosystems, CA, USA).

\subsection{Extraction of polyphenolic compounds}

Healthy berries from each accession (ca. $5 \mathrm{~g}$ ) were extracted with $100 \mathrm{~mL}$ of $80 \% \mathrm{MeOH}$ for $2 \mathrm{~h}$, under stirring (300 rpm) after flushing with nitrogen in order to prevent oxidations during extraction. The extract was centrifuged (10 min, $4000 \mathrm{rpm}$ ) and the material was re-extracted with $100 \mathrm{~mL}$ of $80 \% \mathrm{MeOH}$ (15 min). The combined supernatants were evaporated to dryness under reduced pressure, at $30^{\circ} \mathrm{C}$. The residue was dissolved in $50 \mathrm{~mL}$ of deionized water and applied on the SPE cartridge, preconditioned with $20 \mathrm{~mL}$ of ethyl acetate, $20 \mathrm{~mL}$ of methanol and $20 \mathrm{~mL}$ of $0.01 \mathrm{~N} \mathrm{HCl}$. Non-colored phenolics (fraction I) and anthocyanins (fraction II) were eluted with $20 \mathrm{~mL}$ of ethyl acetate and $40 \mathrm{~mL}$ of methanol containing $0.1 \% \mathrm{HCl}$, respectively. The eluates were concentrated under reduced pressure and the residues obtained were redissolved in appropriate volume of methanol (fraction I) and acidified water ( $\mathrm{pH}$ 3.0) (fraction II), membrane-filtered $(0.45 \mu \mathrm{m})$ and an aliquot of $20 \mu \mathrm{L}$ was injected into an HPLC-DAD system.

\subsection{HPLC-DAD analysis of polyphenolic compounds}

Non-colored phenolic compounds and anthocyanins were analyzed on an analytical HPLC unit (Gilson), using a Spherisorb ODS2 column $(25.0 \mathrm{~cm} \times 0.46 \mathrm{~cm}, 5 \mu \mathrm{m}$ particle size; Waters, Milford, MA, USA).

\subsubsection{Non-colored compounds}

The mobile phase solvents consisted of $2 \%(\mathrm{v} / \mathrm{v})$ acetic acid in water (eluent $\mathrm{A}$ ) and $0.5 \%(\mathrm{v} / \mathrm{v})$ acetic acid in water and acetonitrile (50:50, v/v, eluent B) using a gradient program as follows: from $10 \%$ to $24 \%$ B ( $20 \mathrm{~min}$ ), from $24 \%$ to $30 \%$ B ( $20 \mathrm{~min}$ ), from $30 \%$ to $55 \%$ B ( $20 \mathrm{~min}$ ), from $55 \%$ to $70 \%$ B ( $5 \mathrm{~min}$ ), from $70 \%$ to $80 \%$ B ( $5 \mathrm{~min}$ ), from $80 \%$ to $100 \%$ ( $5 \mathrm{~min}$ ), $100 \%$ B isocratic ( $5 \mathrm{~min}$ ). Flow rate was $1.0 \mathrm{~mL} / \mathrm{min}$. Chromatograms were registered at 280,320 and $350 \mathrm{~nm}$. Compounds were identified by comparing their retention times and UV spectra with those of authentic standards and with literature data (Dopico-García et al., 2008). Quantification was performed by external standard method. Flavan-3-ols, syringic and gallic acids were determined at $280 \mathrm{~nm}$, hydroxycinnamic derivatives and resveratrol-3-O-glucoside were quantified at $320 \mathrm{~nm}$ and flavonols at $350 \mathrm{~nm}$. Coutaric acid was determined as $p$-coumaric acid and the other compounds as themselves. Standards and samples were analyzed in triplicate.

\subsubsection{Anthocyanins}

The mobile phase consisted of water/formic acid/acetonitrile $(87: 10: 3, v / v / v$, eluent $A ; 40: 10: 50, v / v / v$; eluent $B)$ using a gradient program as follows: from $10 \%$ to $25 \%$ B ( $10 \mathrm{~min}$ ), from $25 \%$ to $31 \%$ B ( $5 \mathrm{~min}$ ), from $31 \%$ to $40 \%$ ( $5 \mathrm{~min}$ ), from $40 \%$ to $50 \%$ B $(10 \mathrm{~min})$, from $50 \%$ to $100 \% \mathrm{~B}(10 \mathrm{~min})$. Flow rate was $0.8 \mathrm{~mL} / \mathrm{min}$. Detection was performed at $500 \mathrm{~nm}$. Compounds were identified by comparing their chromatographic behavior and UV spectra with those of authentic standards and with literature data (Dopico-García et al., 2008). Quantification was performed by external standard method. Petunidin-3-O-p-coumaroylglucoside and petunidin-3-O-glucoside were quantified as petunidin; peonidin-3-O-p-coumaroylglucoside and malvidin-3-O- $p$ coumaroylglucoside were determined as peonidin-3-O-glucoside and malvidin-3-0-glucoside, respectively. The other compounds were determined as themselves. Standards and samples were analyzed in triplicate.

\subsection{Statistical analysis}

Principal component analysis (PCA) was carried out using SPSS ${ }^{\circledR}$ 21.0 software (IBM, NY, USA). PCA was applied for reducing the number of variables (24 variables corresponding to each identified phenolic compound: gallic acid, caftaric acid, coutaric acid, catechin, syringic acid, epicatechin, epigallocatechin gallate, epicatechin gallate, resveratrol-3-O-glucoside, myricetin-3-O-glucoside, 
quercetin-3-O-galactoside, quercetin-3-O-rutinoside, quercetin-3$O$-glucoside, kaempferol-3-O-glucoside, isorhamnetin-3$\mathrm{O}$-glucoside, syringetin-3-O-glucoside, delphinidin-3-O-glucoside, cyanidin-3-O-glucoside, petunidin-3-O-glucoside, peonidin-3-Oglucoside, malvidin-3-O-glucoside, petunidin-3-O- $p$ coumaroylglucoside, peonidin-3-O- $p$-coumaroylglucoside and malvidin-3-O-p-coumaroylglucoside) to a smaller number of the new derived variables (principal components, PCs) that adequately summarize the original information, i.e., the phenolic composition of the grape berry skin color mutant cultivars. PCA method shows similarities between samples projected on a plan and makes it possible to identify which variables determine these similarities and in what way.

\section{Results and discussion}

\subsection{Microsatellite analysis for grape berry color mutants identification}

In the last years, developments in DNA analysis for varieties discrimination through microsatellite fingerprinting in viticulture has become the technique of choice for grape varietal identification and distinction (Bowers, Dangl, Vignani, \& Meredith, 1996; Sefc, Regner, Turetschek, Glossl, \& Steinkellner, 1999). Several grapevine varieties develop color mutants, originating new cultivars, in which phenotypic identification can be difficult before the fruit setting. However, these cultivars have the same profile than the original variety if they are analyzed by using microsatellite markers, thus facilitating the identification of the true grape berry color mutants. The European project GENRES\#081 established a set of six microsatellite markers, which was included in the 'Descriptor List for Grapevine Varieties and Vitis Species' and used in this study (OIV, 2009). Although these six microsatellite loci are considered as the minimal standard marker set for grapevine cultivar identification, one other group of six microsatellite loci were amplified in order to proceed to a more accurate grape cultivar authentication (Table 1).

In this study, eleven groups of two or three accessions, with names suggesting the existence of berry skin color mutation were characterized with microsatellites. By comparison with published profiles, identification of most of the varieties was confirmed, and six new genotypes were detected (Table 1 ).

As a consequence of the microsatellite analysis, eleven of the twenty-five accessions were selected and identified as true berry skin color mutants, belonging to five distinct varieties: Malvasia Fina, Gouveio, Moscatel Galego, Pinot, and Pique-Poul (shaded in gray in Table 1), which were used for polyphenols composition analysis. The remaining cases, Alvarelhão, Carrega, Mourisco, and Touriga, the supposed color mutation were discarded.

Bastardo Branco, Moscatel Galego Tinto, the two Malvasia Fina and Gouveio, and the three Pinot profiles were confirmed by comparison with previously published results (Pinto-Carnide et al., 2003; Veloso et al., 2010) (Table 1). Carrega Tinto and Touriga Tinto were identified as Tinta Grossa (Veloso et al., 2010) and Touriga Franca (Martín et al., 2006), respectively (Table 1). Furthermore, Mourisco was identified as Marufo (Castro, Martín, Ortiz, \& Pinto-Carnide, 2011).

Moreover, synonymies with Spanish cultivars were also confirmed, namely Alvarelhão with Brancellao; Alvarelhão Branco with Prieto Picudo Blanco I; Gouveio and Gouveio Roxo with Godello; Moscatel Galego Branco and Moscatel Galego Roxo with Moscatel de Grano Menudo (Martín, Borrego, Cabello, \& Ortiz, 2003), Malvasia Rei with Palomino Fino (EU-VITIS, 2015) and Pique-Poul Gris and Pique-Poul Noir with Picapoll Negro (Cabello et al., 2012) (Table 1). As it can be observed, microsatellites profiles were the same for color mutants (Table 1 ).
The three Bastardo accessions showed different profiles although Bastardo and Bastardo Branco had always at least one allele of each loci in common, indicating a possible parentage relationship among them. The same occurred with Malvasia Rei and Malvasia Rei Tinto, and also with Moscatel Galego Tinto and Moscatel Galego Branco.

\subsection{Polyphenolic compounds}

Twenty-four polyphenolic compounds, distributed by colored and non-colored compounds, were identified (Figs. 1 and 2) and quantified (Table 2) in all berry skin color mutants selected by SSRs.

\subsubsection{Non-colored compounds}

Among non-colored polyphenolic compounds, four phenolic acids, eleven flavonoids and one stilbene were identified (Table 2).

3.2.1.1. Phenolic acids. Gallic (1), syringic (5), caftaric (2) and coutaric (3) acids were the four phenolic acids identified in all studied mutants (Fig. 1, Table 2). Phenolic acids constituted one of the less represented group of non-colored compounds, both in colored and non-colored variants (Table 2), as also previously observed by Liang et al. (2011).

Among hydroxybenzoic acids, with exception of Pinot Gris, the content of gallic acid (1) was higher than that of syringic acid (5). Caftaric acid (2) was the main hydroxycinnamic acid.

Pinot Noir revealed the highest amount of both hydroxybenzoic (ca. $71 \mathrm{mg} / \mathrm{kg}$ dry berry) and hydroxycinnamic acids (ca. $58 \mathrm{mg} / \mathrm{kg}$ dry berry) (Table 2).

3.2.1.2. Flavan-3-ols. Four flavan-3-ols were identified: catechin (4), epicatechin (6), epigallocatechin gallate (7) and epicatechin gallate (8) (Fig. 1, Table 2). Epigallocatechin gallate (7), which is negatively correlated with astringency (Quijada-Morín et al., 2012), was not detected in five of the berry skin color mutants (Table 2), namely in the black mutant variants, Pinot Noir and Pique-Poul Noir and also in Pinot Gris, Gouveio and Gouveio Roxo (Table 2). Despite, this compound was detected in the remaining mutants, in general, its representativeness was reduced when compared with the other three flavan-3-ols. Catechin (4) gave the highest contribution for the amount of this class of flavonoids, representing more than $62 \%$ of total flavan-3-ols in all berry skin color mutants (Table 2). The highest concentrations of flavan-3-ols are generally found in green grapes and decrease during ripening (Mulinacci et al., 2008). Although these compounds are located in both grapes seed and skin, concentrations are much lower in the last. In addition, their composition is also different, skin containing both flavan-3-ols and their galloylated forms, whereas seed presents mainly the first (González-Manzano, Rivas-Gonzalo, \& Santos-Buelga, 2004). Catechin usually is the main flavanol in both skin and seed, although epicatechin is also well represented; however, in some grape cultivars, these monomers are found at similar levels or the amount of epicatechin is higher (Dopico-García et al., 2008; Escribano-Bailón, Guerra, Rivas-Gonzalo, \& Santos-Buelga, 1995; Santos-Buelga, Francia-Aricha, \& Escribano-Bailón, 1995).

Pinot Gris was the richest mutant in flavan-3-ols (ca. $2127 \mathrm{mg} / \mathrm{kg}$ dry berry), showing even higher quantities than its black variant, Pinot Noir ( $1415 \mathrm{mg} / \mathrm{kg}$ dry berry) (Table 2). Among white mutants, the one corresponding to Pinot variety (Pinot Blanc) also revealed high content of flavan-3-ols (ca. $871 \mathrm{mg} / \mathrm{kg}$ dry berry). In opposition, Malvasia Fina was the poorest in this kind of compounds, considering both its white and red variants (ca. $121 \mathrm{mg} / \mathrm{kg}$ of dry berry and ca. $132 \mathrm{mg} / \mathrm{kg}$ of dry berry, respectively) (Table 2 ). 
Table 1

Results of the analysis with twelve SSR loci in eleven groups of $V$. vinifera L. accessions, each group including two or three accessions that presumably could be skin color mutants.

\begin{tabular}{|c|c|c|c|c|c|c|c|c|c|c|c|c|c|c|c|c|c|c|c|c|c|c|c|c|c|c|}
\hline \multirow{4}{*}{$\begin{array}{l}\text { Cultivar name } \\
\text { Alvarelhão } \\
\text { Alvarelhão Branco }\end{array}$} & \multirow{4}{*}{$\begin{array}{l}\text { Berry } \\
\text { color }\end{array}$} & \multicolumn{24}{|c|}{ SSR loci } & \multirow{4}{*}{$\begin{array}{l}\text { Identified SSR profile } \\
\text { Brancellao (a) } \\
\text { Prieto Picudo Blanco I (a) }\end{array}$} \\
\hline & & \multicolumn{2}{|c|}{ VVS2 } & \multicolumn{2}{|c|}{ VVMD5 } & \multicolumn{2}{|c|}{ VVMD7 } & \multicolumn{2}{|c|}{ VVMD27 } & \multicolumn{2}{|c|}{ VrZAG62 } & \multicolumn{2}{|c|}{ VrZAG79 } & \multicolumn{2}{|c|}{ VMC4f3 } & \multicolumn{2}{|c|}{ VVMD28 } & \multicolumn{2}{|c|}{ VVMD32 } & \multicolumn{2}{|c|}{ VVIp31 } & \multicolumn{2}{|c|}{ VVIv37 } & \multicolumn{2}{|c|}{ VVIv67 } & \\
\hline & & 130 & 150 & 218 & 222 & 237 & 237 & 181 & 185 & 187 & 193 & 249 & 257 & 171 & 177 & 231 & 255 & 237 & 253 & 186 & 190 & 163 & 173 & 355 & 360 & \\
\hline & & 140 & 156 & 232 & 236 & 237 & 237 & 175 & 181 & 185 & 185 & 249 & 249 & 181 & 185 & 233 & 255 & 249 & 259 & 174 & 188 & 155 & 155 & 353 & 360 & \\
\hline Bastardo & $\mathrm{N}$ & 140 & 148 & 222 & 234 & 255 & 255 & 171 & 185 & 187 & 187 & 243 & 245 & 165 & 177 & 231 & 245 & 237 & 253 & 178 & 188 & 159 & 167 & 368 & 371 & New genotype \\
\hline Basta & $\mathrm{R}$ & & 140 & 224 & 232 & 245 & 251 & 175 & 181 & 187 & 193 & 243 & 249 & 171 & 187 & 233 & 255 & 253 & 259 & 180 & 194 & 159 & 173 & NA & NA & \\
\hline Bastardo Branco & B & 140 & 148 & 222 & 234 & 255 & 255 & 171 & 185 & 187 & 187 & 243 & 249 & 177 & 177 & 231 & 231 & 237 & 253 & 188 & 190 & 159 & 161 & 371 & 371 & Bastardo (b) \\
\hline Carre & B & 132 & 142 & 224 & 232 & 245 & 245 & 182 & 181 & 191 & 193 & 237 & 249 & 163 & 171 & 231 & 243 & 249 & 259 & 192 & 194 & 167 & 173 & 360 & 368 & $\mathrm{~N}$ \\
\hline Carrega Tinto & $\mathbb{N}$ & 140 & 148 & 230 & 234 & 237 & 251 & 175 & 191 & 187 & 199 & 249 & 255 & 165 & 204 & 245 & 255 & 249 & 269 & 174 & 178 & 157 & 159 & 361 & 368 & Tinta Grossa (b) \\
\hline Gouveio & B & 150 & 156 & 222 & 234 & 237 & 241 & 181 & 185 & 185 & 187 & 249 & 249 & 177 & 185 & 231 & 255 & 249 & 269 & 178 & 188 & 159 & 167 & 363 & 368 & Gouveio, Godello (a, b) \\
\hline Gouveio Roxo & $\mathrm{R}$ & 150 & 156 & 222 & 234 & 237 & 241 & 181 & 185 & 185 & 187 & 249 & 249 & 177 & 185 & 231 & 255 & 249 & 269 & 178 & 188 & 159 & 167 & 363 & 368 & Gouveio, Godello (a, b) \\
\hline Malvasia Fina & B & 140 & 142 & 222 & 236 & 237 & 255 & 175 & 191 & 187 & 187 & 245 & 249 & 165 & 204 & 231 & 233 & 249 & 253 & 188 & 188 & 157 & 159 & 368 & 371 & Malvasia Fina $(b, c)$ \\
\hline Fina Roxo & $\mathrm{R}$ & 140 & 142 & 222 & 236 & 237 & 255 & 175 & 191 & 187 & 187 & 245 & 249 & 165 & 204 & 231 & 233 & 249 & 253 & 188 & 188 & 157 & 159 & 368 & 371 & ia Fina $(b, c)$ \\
\hline Malvasia Rei & B & 140 & 142 & 224 & 236 & 237 & 247 & 181 & 191 & 187 & 193 & 249 & 255 & 173 & 204 & 233 & 245 & 253 & 255 & 186 & 188 & 159 & 163 & 360 & 361 & $\begin{array}{l}\text { Malvasia Rei, Palomino } \\
\text { Fino (d) }\end{array}$ \\
\hline Malvasia Rei Tinto & $\mathrm{N}$ & 130 & 142 & 224 & 236 & 237 & 247 & 181 & 185 & 187 & 193 & 241 & 249 & 171 & 173 & 231 & 245 & 253 & 269 & 188 & 190 & 159 & 163 & 353 & 361 & New genotype \\
\hline $\begin{array}{l}\text { Moscatel Galego } \\
\text { Branco }\end{array}$ & B & 130 & 130 & 224 & 232 & 231 & 247 & 175 & 191 & 185 & 195 & 249 & 253 & 165 & 204 & 243 & 265 & 261 & 269 & 182 & 186 & 159 & 161 & 360 & 371 & $\begin{array}{l}\text { Moscatel de Grano } \\
\text { menudo (a) }\end{array}$ \\
\hline $\begin{array}{l}\text { Moscatel Galego } \\
\text { Roxo }\end{array}$ & $\mathrm{R}$ & 130 & 130 & 224 & 232 & 231 & 247 & 175 & 191 & 185 & 195 & 249 & 253 & 165 & 204 & 243 & 265 & 261 & 269 & 182 & 186 & 159 & 161 & 360 & 371 & $\begin{array}{l}\text { Moscatel de Grano } \\
\text { menudo (a) }\end{array}$ \\
\hline $\begin{array}{l}\text { Moscatel Galego } \\
\text { Tinto }\end{array}$ & $\mathrm{N}$ & 130 & 148 & 222 & 224 & 237 & 247 & 175 & 185 & 185 & 187 & 249 & 253 & 171 & 204 & 243 & 255 & 237 & 261 & 182 & 186 & 159 & 173 & 360 & 371 & Moscatel Galego Tinto (b) \\
\hline Mourisco & $\mathrm{N}$ & 14 & 142 & 224 & 228 & 237 & 241 & 179 & 191 & 187 & 191 & 245 & 255 & 173 & 181 & 241 & 251 & 237 & 249 & 174 & 190 & 155 & 159 & 353 & 361 & Marufo (e) \\
\hline Mourisco Branco & B & 130 & 140 & 222 & 222 & NA & NA & 179 & 185 & 187 & 103 & 245 & 249 & 177 & 181 & 225 & 245 & 237 & 249 & 178 & 186 & 159 & 163 & 360 & 371 & New genotype \\
\hline Pinot Blanc & B & 134 & 148 & 224 & 234 & 237 & 241 & 181 & 185 & 187 & 193 & 237 & 243 & 171 & 177 & 215 & 233 & 237 & 269 & 178 & 182 & 149 & 159 & 360 & 368 & Pinot (b) \\
\hline Pinot Gris & $\mathrm{R}$ & 134 & 148 & 224 & 234 & 237 & 241 & 181 & 185 & 187 & 193 & 237 & 243 & 171 & 177 & 215 & 233 & 237 & 269 & 178 & 182 & 149 & 159 & 360 & 368 & Pinot (b) \\
\hline Pinot Noir & $\mathrm{N}$ & 134 & 148 & 224 & 234 & 237 & 241 & 181 & 185 & 187 & 193 & 237 & 243 & 171 & 177 & 215 & 233 & 237 & 269 & 178 & 182 & 149 & 159 & 360 & 368 & Pinot (b) \\
\hline Pique-Poul G & $\mathrm{R}$ & 130 & 130 & 222 & 228 & 237 & 241 & 175 & 185 & 187 & 187 & 249 & 249 & 171 & 204 & 231 & 233 & 237 & 259 & 178 & 182 & 159 & 161 & 358 & 360 & Picapoll Negro (f) \\
\hline Pique-Poul Noir & $\mathrm{N}$ & 130 & 130 & 222 & 228 & 237 & 241 & 175 & 185 & 187 & 187 & 249 & 249 & 171 & 204 & 231 & 233 & 237 & 259 & 178 & 182 & 159 & 161 & 358 & 360 & Picapoll Negro (f) \\
\hline Tou & B & 132 & 142 & 22 & 23 & 245 & 245 & 181 & 181 & 19 & 19 & 23 & 24 & 16 & 17 & 23 & 243 & 249 & 253 & 192 & 19 & 167 & 173 & 360 & 368 & $\mathrm{~N}$ \\
\hline Touriga Tinto & $\mathrm{N}$ & 140 & 150 & 222 & 224 & 237 & 241 & 177 & 179 & 191 & 193 & 243 & 245 & 173 & 204 & 231 & 251 & 237 & 269 & 174 & 182 & 155 & 159 & 353 & 363 & Touriga Franca (g) \\
\hline
\end{tabular}

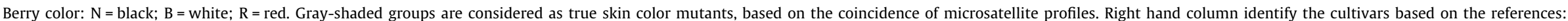
(a) Martín et al. (2003); (b) Veloso et al. (2010); (c) Pinto-Carnide et al. (2003); (d) http://www.eu-vitis.de; (e) Castro et al. (2011); (f) Cabello et al. (2012); (g) Martín et al. (2006). NA = not amplified. 

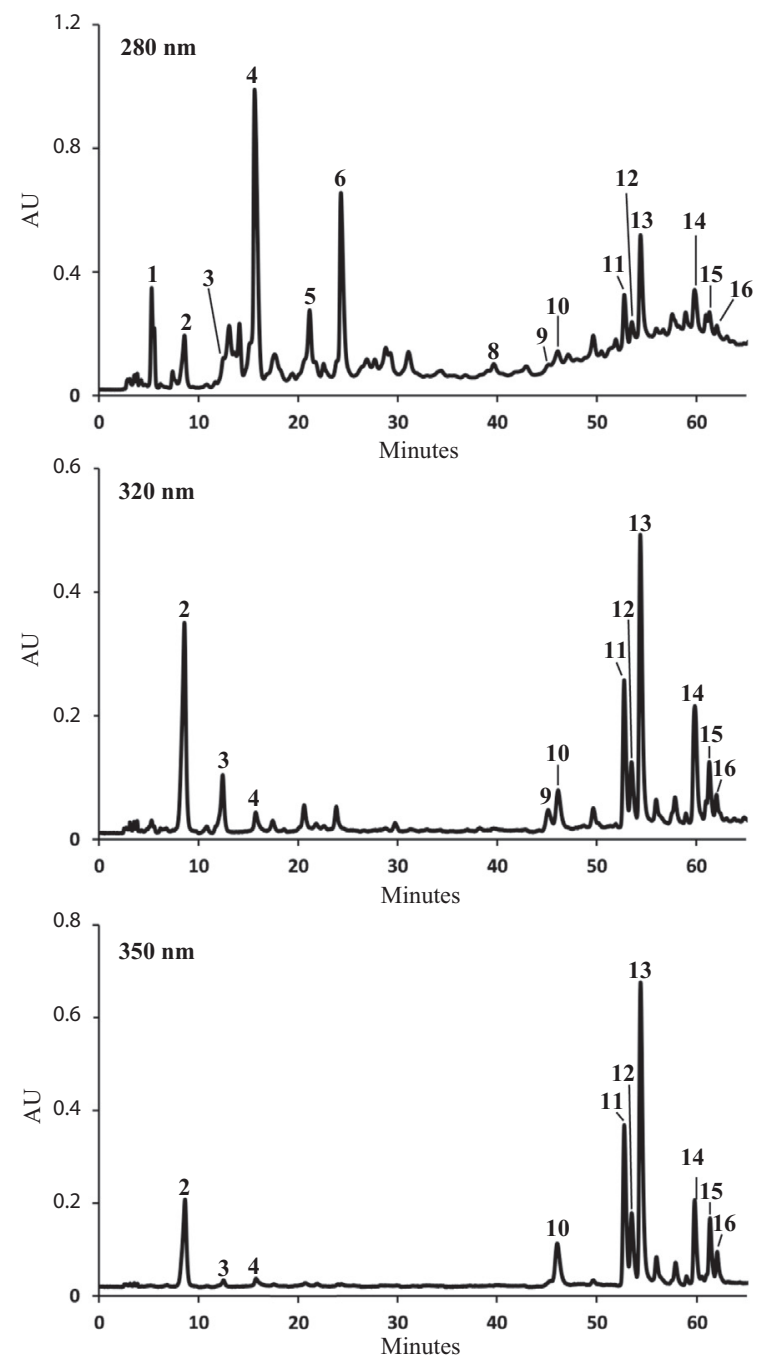

Fig. 1. HPLC-DAD chromatogram of non-colored phenolics of $V$. vinifera cv. Pinot Noir grapes hydromethanolic extract. (1) Gallic acid; (2) Caftaric acid; (3) Coutaric acid; (4) Catechin; (5) Syringic acid; (6) Epicatechin; (7) Epigallocatechin gallate; (8) Epicatechin gallate; (9) Resveratrol-3-O-glucoside; (10) Myricetin-3-Oglucoside; (11) Quercetin-3-O-galactoside; (12) Quercetin-3-O-rutinoside; (13) Quercetin-3-O-glucoside; (14) Kaempferol-3-O-glucoside; (15) Isorhamnetin-3-Oglucoside; (16) Syringetin-3-O-glucoside.

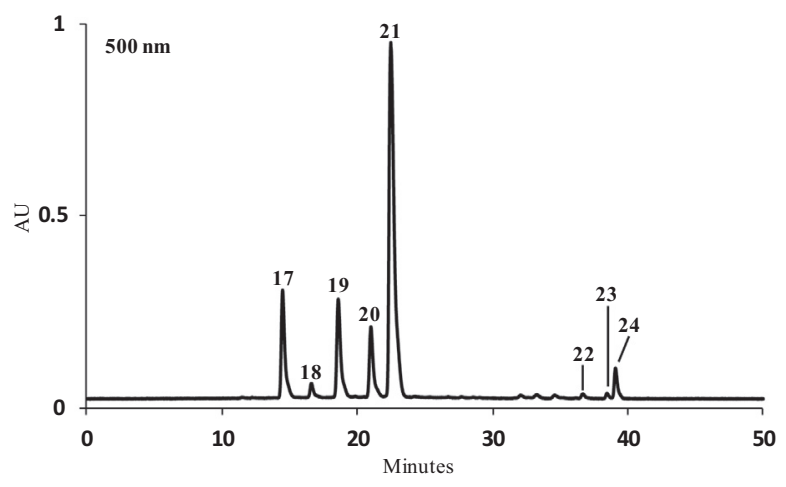

Fig. 2. HPLC-DAD chromatogram of anthocyanins from $V$. vinifera cv. Pinot Noir grapes hydromethanolic extract. (17) Delphinidin-3-O-glucoside; (18) Cyanidin-3O-glucoside; (19) Petunidin-3-O-glucoside; (20) Peonidin-3-O-glucoside; (21) Malvidin-3-O-glucoside; (22) Petunidin-3-O-p-coumaroylglucoside; (23) Peonidin-3-O-p-coumaroylglucoside; (24) Malvidin-3-O-p-coumaroylglucoside.
3.2.1.3. Flavonols. Several flavonols, including 3-O-glycosides of myricetin (10), quercetin (11-13), kaempferol (14), isorhamnetin (15) and syringetin (16), were found (Table 2). Myricetin-3-Oglucoside (10) was only detected in Pinot Noir (Fig. 1, Table 2). Moreover, Moscatel Galego Roxo, Pinot Gris and Pinot Noir were the only mutants that presented syringetin-3-O-glucoside (16).

Pique-Poul Gris revealed the highest flavonols content (ca. $258 \mathrm{mg} / \mathrm{kg}$ dry berry), quercetin-3-O-galactoside (11) accounting for $39 \%$ of the flavonols determined in this skin color mutant variant (Table 2). In fact, quercetin derivatives were the most represented flavonols in all mutant variants, ranging between $66 \%$ and 98\% of the compounds in Gouveio and Pique-Poul Noir, the poorest and richest mutant variants, respectively.

3.2.1.4. Stilbenes. Only one stilbene, resveratrol-3-O-glucoside (9), was found, being present in all berry skin color mutants (Fig. 1, Table 2). With the exception of Pinot Noir, that was the richest mutant in this stilbene (Table 2), red berry-grapes showed higher resveratrol-3-O-glucoside levels than their white and black berry-grapes variants. However, resveratrol-3-O-glucoside (9) did not represent more than $4 \%$ of total non-colored compounds content in all berry skin color mutants.

\subsubsection{Anthocyanins}

In this study, eight anthocyanins were identified (Fig. 2, Table 2). The detected compounds were monoglucoside derivatives of five anthocyanidins, (delphinidin (17), cyanidin (18), petunidin (19 and 22), peonidin (20 and 23) and malvidin (21 and 24)), some of them being also acyl derivatives (compounds 22, 23 and 24).

Anthocyanins are synthesized in grape cells at the cytosolic surface of the endoplasmic reticulum, by a multienzyme complex via the flavonoid pathway (Boss, Davies, \& Robinson, 1996). The genes encoding the early steps enzymes of the polyphenolic biosynthetic pathway, namely chalcone synthase, chalcone isomerase and flavanone-3-hydroxylase, belong to multicopy families and the different number gene copies may have temporal and spatial partitioned expression profiles that sometimes coincide with the biosynthesis of a particular flavonoid (Kuhn et al., 2014).

As expected, these colored polyphenols were only found in black and red mutant variants. However, two exceptions were observed, namely in Malvasia Fina Roxo and Gouveio Roxo. Despite Malvasia Fina Roxo revealed some red pigmentation in its skin berry, it did not presented detectable amounts of anthocyanins. The anthocyanins composition is affected by the expression of flavonoid $3^{\prime} 5^{\prime}$-hydroxylase $\left(\mathrm{F}^{\prime} 5^{\prime} \mathrm{H}\right)$ and flavonoid $3^{\prime}$-hydroxylase $\left(\mathrm{F}^{\prime} \mathrm{H}\right)$ genes. $\mathrm{F}^{\prime} 5^{\prime} \mathrm{H}$ genes are present in highly redundant copy numbers and only two copies of F $3^{\prime} \mathrm{H}$ genes are found in the grape genome, being one copy expressed and the other transcriptionally silent (Kuhn et al., 2014). The prevalence of $\mathrm{F}^{\prime} 5^{\prime} \mathrm{H}$ over $\mathrm{F}^{\prime} \mathrm{H}$ in black cultivars would lead to the presence of more delphinidin, the precursor of blue/purple petunidin and malvidin derivatives, and, in contrast, it would yield less cyanidin, the precursor of the red peonidin derivatives (Kuhn et al., 2014). On this way, the lack of detectable amounts of anthocyanins in Malvasia Fina Roxo suggests a lack of activity of both $\mathrm{F}^{\prime} 5^{\prime} \mathrm{H}$ and F3' $\mathrm{H}$ genes. Another possibility that can influence and be behind the color observed in Malvasia Fina Roxo is the synthesis of other compounds, such as carotenoids, which are lipid soluble pigments found in many vegetable crops (Jackson, 2008) usually masked by the presence of anthocyanins that donates the dominant color. Moreover, in the field no detectable skin color development was observed for Gouveio Roxo during ripening, which suggests that these compounds were not being synthesized. The variation of anthocyanin composition and concentration in grapes is a consequence of many factors, such as cultivar, climate (like sunlight exposure, UV irradiation, temperature), canopy management, 
Table 2

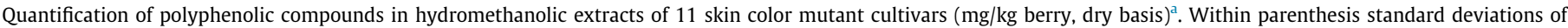

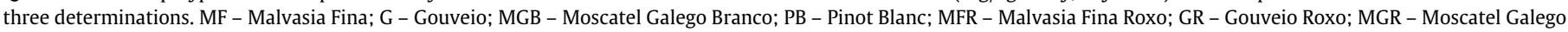
Roxo; PPG - Pique-Poul Gris; PG - Pinot Gris; PPN -Pique-Poul Noir; PN - Pinot Noir.

\begin{tabular}{|c|c|c|c|c|c|c|c|c|c|c|c|c|}
\hline & & \multicolumn{4}{|c|}{ White cultivars } & \multicolumn{5}{|c|}{ Red cultivars } & \multicolumn{2}{|c|}{ Black cultivars } \\
\hline & & MF & G & MGB & $\mathrm{PB}$ & MFR & GR & MGR & PPG & PG & PPN & PN \\
\hline \multicolumn{13}{|l|}{ Phenolic acids } \\
\hline \multicolumn{13}{|l|}{ Hydroxybenzoic acids } \\
\hline (1) Gallic acid & & $\begin{array}{l}5.7 \\
(0.1)\end{array}$ & $8.1(0.1)$ & $\begin{array}{l}19.2 \\
(0.5)\end{array}$ & $\begin{array}{l}18.3 \\
(0.0)\end{array}$ & $\begin{array}{l}11.6 \\
(0.6)\end{array}$ & $\begin{array}{l}9.8 \\
(0.2)\end{array}$ & $\begin{array}{l}19.6 \\
(0.1)\end{array}$ & $\begin{array}{l}24.4 \\
(0.3)\end{array}$ & $16.1(0.3)$ & $\begin{array}{l}15.1 \\
(0.3)\end{array}$ & $38.4(0.0)$ \\
\hline (5) Syringic acid & & $\begin{array}{l}5.5 \\
(0.0)\end{array}$ & $7.0(0.1)$ & $\begin{array}{l}11.4 \\
(0.3)\end{array}$ & $\begin{array}{l}17.2 \\
(0.1)\end{array}$ & $9.7(0.8)$ & $\begin{array}{l}7.0 \\
(0.0)\end{array}$ & $5.7(0.0)$ & $\begin{array}{l}10.8 \\
(0.9)\end{array}$ & $20.2(1.1)$ & $6.8(0.1)$ & $32.8(2.0)$ \\
\hline \multicolumn{13}{|l|}{ Hydroxycinnamic acids } \\
\hline (2) Caftaric acid & & $\begin{array}{l}22.8 \\
(0.2)\end{array}$ & $\begin{array}{l}10.5 \\
(0.2)\end{array}$ & $\begin{array}{l}24.0 \\
(0.3)\end{array}$ & $\begin{array}{l}28.1 \\
(0.2)\end{array}$ & $\begin{array}{l}15.8 \\
(0.1)\end{array}$ & $\begin{array}{l}14.9 \\
(0.1)\end{array}$ & $\begin{array}{l}45.4 \\
(0.5)\end{array}$ & $\begin{array}{l}44.2 \\
(0.3)\end{array}$ & $12.1(0.4)$ & $\begin{array}{l}10.1 \\
(0.1)\end{array}$ & $53.9(0.2)$ \\
\hline \multirow[t]{2}{*}{ (3) Coutaric acid } & & $\begin{array}{l}2.1 \\
(0.1)\end{array}$ & $0.7(0.1)$ & $4.2(0.0)$ & $2.7(0.1)$ & $2.2(0.0)$ & $\begin{array}{l}3.0 \\
(0.0)\end{array}$ & $5.7(0.0)$ & $4.7(0.0)$ & $3.3(0.0)$ & $1.1(0.0)$ & $4.6(0.1)$ \\
\hline & $\sum$ & $\begin{array}{l}36.1 \\
(0.4)\end{array}$ & $\begin{array}{l}26.3 \\
(0.5)\end{array}$ & $\begin{array}{l}58.8 \\
(1.1)\end{array}$ & $\begin{array}{l}66.3 \\
(0.4)\end{array}$ & $\begin{array}{l}39.3 \\
(1.5)\end{array}$ & $\begin{array}{l}34.7 \\
(0.3)\end{array}$ & $\begin{array}{l}76.4 \\
(0.6)\end{array}$ & $\begin{array}{l}84.1 \\
(1.5)\end{array}$ & $51.7(1.8)$ & $\begin{array}{l}33.1 \\
(0.5)\end{array}$ & $\begin{array}{l}129.7 \\
(2.3)\end{array}$ \\
\hline \multicolumn{13}{|l|}{ Flavonoids } \\
\hline \multicolumn{13}{|l|}{ Flavan-3-ols } \\
\hline (4) Catechin & & $\begin{array}{l}88.5 \\
(1.1)\end{array}$ & $\begin{array}{l}391.1 \\
(19.7)\end{array}$ & $\begin{array}{l}408.1 \\
(7.2)\end{array}$ & $\begin{array}{l}589.8 \\
(2.5)\end{array}$ & $\begin{array}{l}83.8 \\
(5.5)\end{array}$ & $\begin{array}{l}341.7 \\
(3.1)\end{array}$ & $\begin{array}{l}379.8 \\
(10.2)\end{array}$ & $\begin{array}{l}261.6 \\
(1.7)\end{array}$ & $\begin{array}{l}1615.5 \\
(34.2)\end{array}$ & $\begin{array}{l}212.5 \\
(1.0)\end{array}$ & $\begin{array}{l}977.0 \\
(4.5)\end{array}$ \\
\hline (6) Epicatechin & & $\begin{array}{l}24.0 \\
(0.0)\end{array}$ & $\begin{array}{l}133.6 \\
(2.1)\end{array}$ & $\begin{array}{l}206.0 \\
(3.1)\end{array}$ & $\begin{array}{l}254.2 \\
(4.6)\end{array}$ & $\begin{array}{l}36.2 \\
(0.7)\end{array}$ & $\begin{array}{l}118.9 \\
(0.2)\end{array}$ & $\begin{array}{l}130.0 \\
(3.2)\end{array}$ & $\begin{array}{l}104.0 \\
(0.7)\end{array}$ & $\begin{array}{l}474.8 \\
(9.5)\end{array}$ & $\begin{array}{l}119.2 \\
(6.7)\end{array}$ & $\begin{array}{l}423.6 \\
(2.9)\end{array}$ \\
\hline (7) Epigallocatechin gallate & & $\begin{array}{l}5.0 \\
(0.1)\end{array}$ & - & $9.0(0.6)$ & $\begin{array}{l}12.7 \\
(2.1)\end{array}$ & $7.2(0.5)$ & - & $5.3(0.0)$ & $6.9(0.1)$ & - & - & - \\
\hline (8) Epicatechin gallate & & $\begin{array}{l}3.3 \\
(0.0)\end{array}$ & $\begin{array}{l}10.3 \\
(0.1)\end{array}$ & $\begin{array}{l}19.9 \\
(0.2)\end{array}$ & $\begin{array}{l}14.4 \\
(0.2)\end{array}$ & $4.4(0.7)$ & $\begin{array}{l}13.9 \\
(0.0)\end{array}$ & $\begin{array}{l}11.5 \\
(0.1)\end{array}$ & $\begin{array}{l}23.4 \\
(1.7)\end{array}$ & $36.4(5.0)$ & $\begin{array}{l}11.7 \\
(0.0)\end{array}$ & $14.4(0.1)$ \\
\hline & $\sum$ & $\begin{array}{l}120.8 \\
(1.2)\end{array}$ & $\begin{array}{l}535.0 \\
(21.9)\end{array}$ & $\begin{array}{l}643.0 \\
(11.1)\end{array}$ & $\begin{array}{l}871.1 \\
(9.4)\end{array}$ & $\begin{array}{l}131.6 \\
(7.4)\end{array}$ & $\begin{array}{l}474.5 \\
(3.3)\end{array}$ & $\begin{array}{l}526.6 \\
(13.5)\end{array}$ & $\begin{array}{l}395.9 \\
(4.2)\end{array}$ & $\begin{array}{l}2126.7 \\
(48.7)\end{array}$ & $\begin{array}{l}343.4 \\
(7.7)\end{array}$ & $\begin{array}{l}1415.0 \\
(7.5)\end{array}$ \\
\hline \multicolumn{13}{|l|}{ Flavonols } \\
\hline (10) Myricetin-3-O-gluc & & - & - & - & - & - & - & - & - & - & - & $20.3(0.8)$ \\
\hline $\begin{array}{l}\text { (11) Quercetin-3-O- } \\
\text { galactoside }\end{array}$ & & $\begin{array}{l}44.6 \\
(0.3)\end{array}$ & $\begin{array}{l}52.4 \\
(0.4)\end{array}$ & $\begin{array}{l}68.2 \\
(1.7)\end{array}$ & $\begin{array}{l}19.7 \\
(0.6)\end{array}$ & $\begin{array}{l}59.7 \\
(0.7)\end{array}$ & $\begin{array}{l}45.9 \\
(1.2)\end{array}$ & $\begin{array}{l}82.2 \\
(0.7)\end{array}$ & $\begin{array}{l}100.6 \\
(1.5)\end{array}$ & $86.8(1.2)$ & $\begin{array}{l}41.9 \\
(0.1)\end{array}$ & $33.8(0.4)$ \\
\hline (12) Quercetin-3-O-rutinoside & & $\begin{array}{l}21.6 \\
(0.4)\end{array}$ & $\begin{array}{l}30.6 \\
(0.1)\end{array}$ & $\begin{array}{l}23.5 \\
(0.5)\end{array}$ & $3.1(0.0)$ & $\begin{array}{l}28.0 \\
(0.7)\end{array}$ & $\begin{array}{l}20.1 \\
(0.1)\end{array}$ & $\begin{array}{l}24.8 \\
(0.2)\end{array}$ & $\begin{array}{l}27.6 \\
(0.3)\end{array}$ & $25.8(0.1)$ & $\begin{array}{l}16.0 \\
(0.2)\end{array}$ & $30.5(0.0)$ \\
\hline (13) Quercetin-3-O-glucoside & & $\begin{array}{l}48.4 \\
(0.3)\end{array}$ & $\begin{array}{l}81.3 \\
(0.5)\end{array}$ & $\begin{array}{l}51.6 \\
(1.1)\end{array}$ & $5.9(0.0)$ & $\begin{array}{l}70.7 \\
(1.2)\end{array}$ & $\begin{array}{l}54.4 \\
(0.7)\end{array}$ & $\begin{array}{l}52.7 \\
(0.6)\end{array}$ & $\begin{array}{l}82.3 \\
(1.7)\end{array}$ & $63.8(0.7)$ & $\begin{array}{l}39.3 \\
(0.2)\end{array}$ & $67.2(1.0)$ \\
\hline $\begin{array}{l}\text { (14) Kaempferol-3-O- } \\
\text { glucoside }\end{array}$ & & $\begin{array}{l}34.9 \\
(0.6)\end{array}$ & $\begin{array}{l}78.6 \\
(0.2)\end{array}$ & $\begin{array}{l}66.8 \\
(1.4)\end{array}$ & $4.5(0.2)$ & $\begin{array}{l}37.0 \\
(1.1)\end{array}$ & $\begin{array}{l}46.5 \\
(0.2)\end{array}$ & $\begin{array}{l}60.3 \\
(0.9)\end{array}$ & $\begin{array}{l}47.4 \\
(1.0)\end{array}$ & $32.6(0.7)$ & $\begin{array}{l}19.4 \\
(0.2)\end{array}$ & $25.8(0.3)$ \\
\hline $\begin{array}{l}\text { (15) Isorhamnetin-3-O- } \\
\text { glucoside }\end{array}$ & & $\begin{array}{l}1.4 \\
(0.1)\end{array}$ & $4.4(0.2)$ & $4.2(0.1)$ & $1.5(0.1)$ & $1.6(0.1)$ & $\begin{array}{l}5.4 \\
(0.1)\end{array}$ & $\begin{array}{l}2.9 \\
(0.0)^{*}\end{array}$ & - & $9.2(0.1)$ & $1.8(0.1)$ & $13.0(0.0)$ \\
\hline (16) Syringetin-3-O-glucoside & & - & - & - & - & - & - & & - & $3.2(0.3)$ & - & $8.6(0.2)$ \\
\hline & $\sum$ & $\begin{array}{l}150.9 \\
(1.7)\end{array}$ & $\begin{array}{l}247.3 \\
(1.4)\end{array}$ & $\begin{array}{l}214.3 \\
(4.8)\end{array}$ & $\begin{array}{l}34.7 \\
(0.9)\end{array}$ & $\begin{array}{l}197.0 \\
(3.8)\end{array}$ & $\begin{array}{l}172.3 \\
(2.3)\end{array}$ & $\begin{array}{l}222.9 \\
(2.4)\end{array}$ & $\begin{array}{l}257.9 \\
(4.5)\end{array}$ & $\begin{array}{l}221.4 \\
(3.1)\end{array}$ & $\begin{array}{l}118.4 \\
(0.8)\end{array}$ & $\begin{array}{l}199.2 \\
(2.7)\end{array}$ \\
\hline \multicolumn{13}{|l|}{ Anthocyanins } \\
\hline $\begin{array}{l}\text { (17) Delphinidin-3-O- } \\
\text { glucoside }\end{array}$ & & - & - & - & - & - & - & $1.6(0.1)$ & - & $0.6(0.0)$ & $1.5(0.1)$ & $81.9(0.6)$ \\
\hline (18) Cyanidin-3-O-glucoside & & - & - & - & - & - & - & $5.1(0.1)$ & $0.7(0.1)$ & $0.1(0.0)$ & $4.3(0.3)$ & $9.9(0.4)$ \\
\hline (19) Petunidin-3-O-glucoside & & - & - & - & - & - & - & $0.4(0.0)$ & - & $2.8(0.4)$ & $2.7(0.0)$ & $94.8(0.5)$ \\
\hline (20) Peonidin-3-O-glucoside & & - & - & - & - & - & - & $1.2(0.2)$ & $0.6(0.0)$ & $7.8(0.2)$ & $\begin{array}{l}13.4 \\
(0.1)\end{array}$ & $52.2(0.5)$ \\
\hline (21) Malvidin-3-O-glucoside & & - & - & - & - & - & - & $0.9(0.1)$ & $0.7(0.2)$ & $79.5(0.1)$ & $\begin{array}{l}25.7 \\
(0.8)\end{array}$ & $\begin{array}{l}448.7 \\
(1.5)\end{array}$ \\
\hline $\begin{array}{l}\text { (22) Petunidin-3-O-p- } \\
\text { coumaroylglucoside }\end{array}$ & & - & - & - & - & - & - & - & - & - & $1.4(0.4)$ & $4.3(0.1)$ \\
\hline $\begin{array}{l}\text { (23) Peonidin-3-O- } p \text { - } \\
\text { coumaroylglucoside }\end{array}$ & & - & - & - & - & - & - & - & $0.3(0.0)$ & - & $2.9(0.1)$ & $3.6(0.0)$ \\
\hline \multirow{2}{*}{$\begin{array}{l}\text { coumaroylglucoside } \\
\text { (24) Malvidin-3-O-p- } \\
\text { coumaroylglucoside }\end{array}$} & & - & - & - & - & - & - & - & $0.3(0.0)$ & - & $3.7(0.1)$ & $27.4(0.1)$ \\
\hline & $\sum$ & - & - & - & - & - & - & $9.2(0.5)$ & $2.6(0.3)$ & $90.8(0.7)$ & $\begin{array}{l}55.6 \\
(1.9)\end{array}$ & $\begin{array}{l}722.8 \\
(3.2)\end{array}$ \\
\hline \multicolumn{13}{|l|}{ Stilbenes } \\
\hline (9) Resveratrol-3-O-glucoside & & $\begin{array}{l}1.4 \\
(0.0)\end{array}$ & $1.1(0.0)$ & $0.9(0.0)$ & $1.7(0.0)$ & $1.9(0.0)$ & $\begin{array}{l}2.0 \\
(0.1)\end{array}$ & $1.2(0.0)$ & $3.7(0.0)$ & $2.1(0.1)$ & $0.7(0.0)$ & $5.5(0.1)$ \\
\hline Total phenols & & $\begin{array}{l}309.2 \\
(3.3)\end{array}$ & $\begin{array}{l}809.7 \\
(23.8)\end{array}$ & $\begin{array}{l}917.0 \\
(17.0)\end{array}$ & $\begin{array}{l}973.8 \\
(10.7)\end{array}$ & $\begin{array}{l}369.8 \\
(12.7)\end{array}$ & $\begin{array}{l}683.5 \\
(6.0)\end{array}$ & $\begin{array}{l}836.3 \\
(17.0)\end{array}$ & $\begin{array}{l}744.2 \\
(10.5)\end{array}$ & $\begin{array}{l}2492.7 \\
(54.4)\end{array}$ & $\begin{array}{l}551.2 \\
(10.9)\end{array}$ & $\begin{array}{l}2472.2 \\
(15.8)\end{array}$ \\
\hline
\end{tabular}

“-": not detected.

a $\sum$ : sum of the identified polyphenolic compounds.

* Isorhmnetin-3-O-glucoside and syringetin-3-O-glucoside were quantified together. 

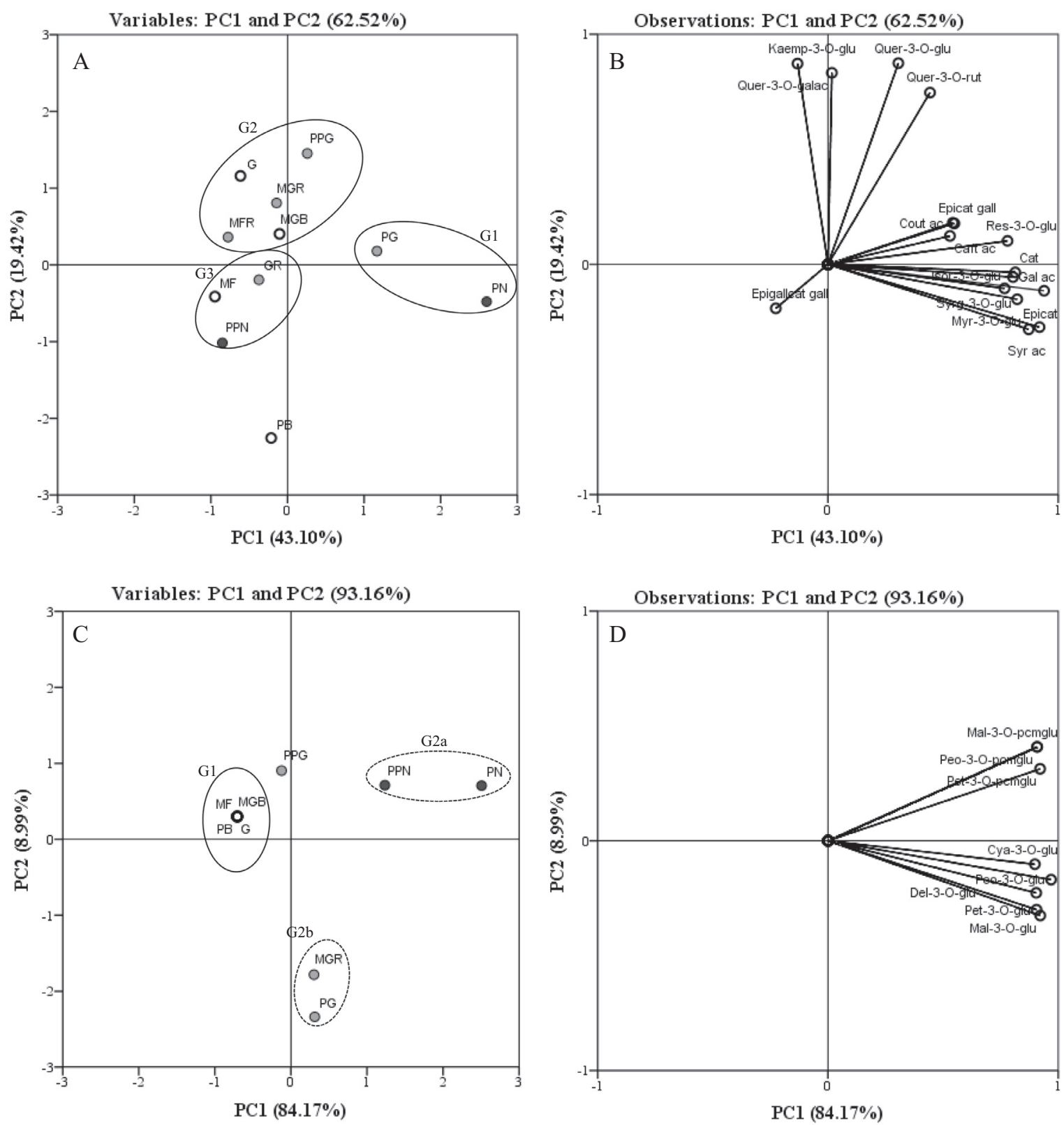

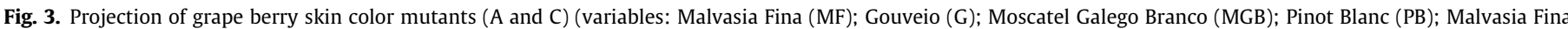

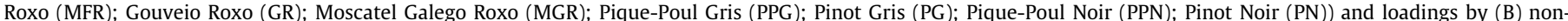

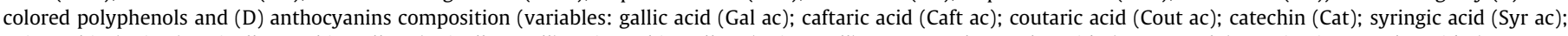

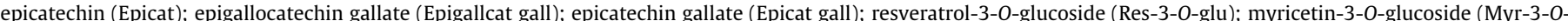

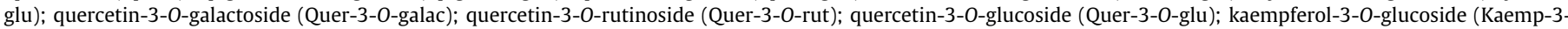

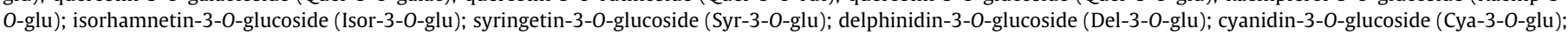

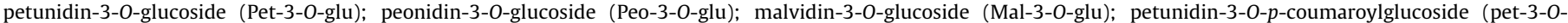

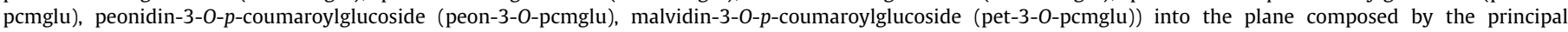
components PC1 and PC2 containing $62.52 \%$ and $93.16 \%$ of the total variance for non-colored polyphenols and anthocyanins composition, respectively.

fertilizers and water regimes, affecting both the expression of the structural and regulatory genes (Downey, Dokoozlian, \& Krstic, 2006; He et al., 2010). Recently, some studies addressed the effects of anti-fungal treatments on the color and phenolic profile of red wines, concluding that, in general, the anti-fungal substances had different effects depending on the cultivar and on the phenolic compound analyzed, usually resulting in less colorful wines (Briz-Cid, Figueiredo-González, Rial-Otero, Cancho-Grande, \& Simal-Gándara, 2014, 2015). Therefore, the accession analyzed and designated as Gouveio Roxo, despite presenting the profile of Gouveio variety, as confirmed by the molecular analysis
(Table 1), it does not correspond to a red variant of Gouveio evidenced by the lack of anthocyanins.

Qualitative differences among berry skin color mutants of the same variety were also seen (Table 2). Pinot Gris did not show the three acylated anthocyanins (compounds 22, 23 and 24) present in Pinot Noir (Table 2).

Delphinidin-3-O-glucoside (17), petunidin-3-O-glucoside (19) and petunidin-3-O-p-coumaroylglucoside (22) were not detected in Pique-Poul Gris, but were found in the other red mutant variants, as well as in its black variant Pique-Poul Noir. However, Pique-Poul Gris presented peonidin-3-O-p-coumaroylglucoside 
(23) and malvidin-3-O-p-coumaroylglucoside (24) that were not detected in the remaining red-colored mutant variants (Table 2). As so, the presence or absence of these compounds could be a specific feature of Pique-Poul Gris, allowing to easily distinguishing this red color variant from the other red variants studied.

Quantitatively, Pinot Noir was clearly the mutant with the highest amount of anthocyanins (ca. $723 \mathrm{mg} / \mathrm{kg}$ dry berry), about eight times more than its red variant, Pinot Gris (ca. $91 \mathrm{mg} / \mathrm{kg}$ dry berry) (Table 2). Liang et al. (2011) described that during the whole course of maturation, the skin cells of colored grapes accumulate anthocyanins and, consequently, the color of the berry is progressively darkened.

Malvidin-3-O-p-glucoside (21) was the major compound in the black mutant variants and in Pinot Gris, although at notably higher concentration in Pinot Noir (ca. $449 \mathrm{mg} / \mathrm{kg}$ dry berry) (Table 2). Pinot Noir is an international cultivar, being much studied concerning to its anthocyanin composition. Dimitrovska, Bocevska, Dimitrovski, and Murkovic (2011) and Mattivi, Guzzon, Vrhovsek, Stefanini, \& Velasco, 2006 reported the anthocyanin profile of Pinot Noir, both showing malvidin-3-O-p-glucoside as the main anthocyanin. However, our results also showed the presence of three acylated derivatives (Fig. 2, Table 2), petunidin3-O-p-coumaroylglucoside, peonidin-3-O-p-coumaroylglucoside and malvidin-3-O-p-coumaroylglucoside (compounds 22, 23 and 24), which, as far as we know, are reported for the first time in this cultivar. This observation provides evidence about the influence of the environmental factors on the anthocyanin pattern.

Our results suggest that different proportions of individual anthocyanins, in addition to their total amount, can affect the color types of grape berry skin color mutants. Considering Pinot Noir, besides malvidin-3-O-glucoside (21), other anthocyanins, namely delphinidin-3-O-glucoside (17), petunidin-3-O-glucoside (19) and peonidin-3-O-glucoside (20), should be highlighted because of their contribution to the total anthocyanins content of this grape (Table 2).

Several authors reported cyanidin derivatives as the minor group of anthocyanins in colored cultivars (Figueiredo-González, Simal-Gándara et al., 2012; Núñez, Monagas, Gomez-Cordovés, \& Bartolomé, 2004). Furthermore, taking into account that cyanidin is the precursor of others anthocyanins, it is usual to find low concentrations of its derivatives in red colored grapes (Núñez et al., 2004). Nevertheless, this was not observed on Moscatel Galego Roxo, suggesting that the $\mathrm{F}^{\prime} \mathrm{H}$ pathway is more active than $\mathrm{F}^{\prime} 5^{\prime} \mathrm{H}$, resulting in higher amounts of cyanidin-3-O-glucoside.

Previous studies described the UDPglucose:flavonoid3-O-glucosyltransferase (UFGT) activity as critical for anthocyanins biosynthesis (Boss et al., 1996; Zheng et al., 2013). The control of the biosynthetic step mediated by UFGT in the anthocyanin pathway is mainly affected by $M y b$ genes family. The presence of Gret1 retrotransposon, in the promotor region of MYBA1, is associated with white-fruited cultivars when present in a homozygous state (Kobayashi, Goto-Yamamoto, \& Hirochika, 2004). Additional polymorphisms in this gene are also strongly associated with a red or pink-fruited phenotype (This, Lacombe, Cadle-Davidson, \& Owens, 2007), which can possibly explain some of the color differences among the different sets of berry color mutants studied.

\subsection{Principal components analysis (PCA)}

To study the relationship between colored and non-colored related berried cultivars and their polyphenolic composition, PCA was applied to the content ( $\mathrm{mg} / \mathrm{kg}$ dry grape) of non-colored compounds (Fig. 3A and B) and anthocyanins (Fig. 3C and D).

PCA of normalized non-colored dataset explained $62.52 \%$ of total variations, PC1 accounting for $43.10 \%$ of the variance and PC2 for $19.42 \%$ (Fig. 3A and B). As shown in Fig. 3A, three groups could be clearly distinguished (Fig. 3A and B). One group (G1) includes the color-related berried Pinot Gris and Pinot Noir. These mutants appeared in the positive plan of PC1, due to the absence of epigallocatechin gallate, but highest content in flavano-3-ols (ca. 2127 and $1415 \mathrm{mg} / \mathrm{kg}$ dry grape, respectively), namely in catechin, as well as the high content of phenolic acids, namely syringic acid. Despite being included in the same group, Pinot Gris appeared in the positive plan of the PC2 and Pinot Noir in the negative one due to the presence of myricetin-3-O-glucoside in the last one. Group G2 included the white variants Gouveio and Moscatel Galego Branco and the red variants Malvasia Fina Roxo, Moscatel Galego Roxo and Pique-Poul Gris due to their high content in glucoside derivatives of kaempferol and quercetin, with particular relevance for Pique-Poul Gris, the richest one. The low amounts of flavonols and phenolic acids in Malvasia Fina, Gouveio Roxo and Pique-Poul Noir led to the inclusion of them in another group (G3) in the negative parts of PC1 and PC2. Pinot Blanc was clearly separated from the other accessions due to its low levels in flavonols (Fig. 3A and B).

PCA of anthocyanins explained $93.16 \%$ of total variation, where PC1 accounts for $84.17 \%$ of the variance and PC2 for $8.99 \%$ (Fig. $3 \mathrm{C}$ and D). Due to the absence of anthocyanins in their composition, white variants, such as Malvasia Fina, Gouveio, Moscatel Galego Branco and Pinot Blanc, were grouped together (G1) in the negative part of PC1 (Fig. 3C and D).

PCA confirmed that the anthocyanin profile was related to the grape skin color. Among color-berried mutants, two subgroups were established (Fig. 3C and D). One group (G2a) that appears in the positive plan of PC1 and PC2 includes the black mutants Pique Poul Noir and Pinot Noir for their content in $p$-coumaroyl derivatives of petunidin, peonidin and malvidin. Another group (G2b) included Moscatel Galego Roxo and Pinot Gris, in which no $p$-coumaroyl derivatives were identified. The red variant Pique-Poul Gris, in which the content of non-acylated anthocyanins was higher than that of acylated ones, was the poorest mutant regarding anthocyanins, appearing in the positive part of PC2, close to the group of white mutant variants (G1).

\section{Conclusions}

The variation of polyphenolic compounds in groups of grape berry skin color mutants, including related black, red and white-berried mutant variants derived from a single variety identified by nuclear microsatellite analysis, was investigated, for the first time. The grape berry skin color mutants were distinguished according to their phenolic acids, flavan-3-ols, flavonols and anthocyanins composition. Molecular and chemical approaches complemented each other in the correct identification of the grape berry skin color mutants.

As expected, anthocyanins were the main group of compounds that allowed a clear division among color and non-colored related mutant variants. The results also revealed differences in the contribution of different anthocyanins to distinguish berry skin color mutants.

The observed chemical richness and differences among related mutant cultivars derived from a single variety encourage the use of berry skin color somatic variants, not only for the development of new cultivars with interesting characteristics, namely concerning the color feature, but also to improve knowledge on colored and non-colored cultivars and understanding the evolutionary events behind their origin.

The study of genes involved in the polyphenolic biosynthesis may help elucidating the genetics behind grape berry skin color and understand how this kind of compounds affected the skin pigmentation of the studied grape berry skin color mutants. 


\section{Acknowledgements}

This work received financial support from the Fundação para a Ciência e Tecnologia (FCT) PTDC/AGRO-PRO/120264/2010 project, the European Union (FEDER funds through COMPETE) and National Funds (FCT) through project Pest-C/EQB/LA0006/2013. The work also received financial support from the European Union (FEDER funds) under the framework of QREN through Project NORTE-07-0124-FEDER-000069. To all financing sources the authors are greatly indebted. F.F. (SFRH/BPD/98732/2013) and V.F. (SFRH/BD/96400/2013) are indebted to FCT for their grants.

\section{References}

Boss, P. K., Davies, C., \& Robinson, S. P. (1996). Analysis of the expression of anthocyanin pathway genes in developing Vitis vinifera L. Cv Shiraz grape berries and the implications for pathway regulation. Plant Physiology, 111(4), 1059-1066.

Bowers, J. E., Dangl, G. S., \& Meredith, C. P. (1999). Development and characterization of additional microsatellite DNA markers for grape. American Journal of Enology and Viticulture, 50(3), 243-246.

Bowers, J. E., Dangl, G. S., Vignani, R., \& Meredith, C. P. (1996). Isolation and characterization of new polymorphic simple sequence repeat loci in grape (Vitis vinifera L.). Genome, 39(4), 628-633.

Briz-Cid, N., Figueiredo-González, M., Rial-Otero, R., Cancho-Grande, B., \& SimalGándara, J. (2014). Effect of two anti-fungal treatments (metrafenone and boscalid plus kresoxim-methyl) applied to vines on the color and phenol profile of different red wines. Molecules, 19(6), 8093-8111. http://dx.doi.org/ 10.3390/molecules19068093.

Briz-Cid, N., Figueiredo-González, M., Rial-Otero, R., Cancho-Grande, B., \& SimalGándara, J. (2015). The measure and control of effects of botryticides on phenolic profile and color quality of red wines. Food Control, 50, 942-948. http://dx.doi.org/10.1016/j.foodcont.2014.10.043.

Burns, J., Gardner, P. T., O'Neil, J., Crawford, S., Morecroft, I., McPhail, D. B., et al. (2000). Relationship among antioxidant activity, vasodilation capacity, and phenolic content of red wines. Journal of Agricultural and Food Chemistry, 48(2), 220-230. http://dx.doi.org/10.1021/jf9909757.

Cabello, F., Ortiz, J. M., Muñoz, G., Rodríguez, I., Benito, A., Rubio, C., et al. (2012). Variedades de vid en España. Editorial Agrícola Española.

Castillo-Muñoz, N., Gómez-Alonso, S., García-Romero, E., \& Hermosín-Gutiérrez, I. (2010). Flavonol profiles of Vitis vinifera white grape cultivars. Journal of Food Composition and Analysis, 23(7), 699-705. http://dx.doi.org/10.1016/ j.jfca.2010.03.017.

Castro, I., Martín, J. P., Ortiz, J. M., \& Pinto-Carnide, O. (2011). Varietal discrimination and genetic relationships of Vitis vinifera L. cultivars from two major Controlled Appellation (DOC) regions in Portugal. Scientia Horticulturae, 127(4), 507-514. http://dx.doi.org/10.1016/j.scienta.2010.11.018.

Di Gaspero, G., Peterlunger, E., Testolin, R., Edwards, K. J., \& Cipriani, G. (2000). Conservation of microsatellite loci within the genus Vitis. Theoretical and Applied Genetics, 101(1-2), 301-308. http://dx.doi.org/10.1007/s001220051483.

Dimitrovska, M., Bocevska, M., Dimitrovski, D., \& Murkovic, M. (2011). Anthocyanin composition of Vranec, Cabernet Sauvignon, Merlot and Pinot Noir grapes as indicator of their varietal differentiation. European Food Research and Technology, 232(4), 591-600. http://dx.doi.org/10.1007/s00217-011-1425-9.

Dopico-García, M. S., Fique, A., Guerra, L., Afonso, J. M., Pereira, O., Valentão, P., et al. (2008). Principal components of phenolics to characterize red Vinho Verde grapes: Anthocyanins or non-coloured compounds? Talanta, 75(5), 1190-1202. http://dx.doi.org/10.1016/j.talanta.2008.01.012.

Downey, M. O., Dokoozlian, N. K., \& Krstic, M. P. (2006). Cultural practice and environmental impacts on the flavonoid composition of grapes and wine: A review of recent research. American Journal of Enology and Viticulture, 57(3), 257-268.

Escribano-Bailón, M. T., Guerra, M. T., Rivas-Gonzalo, J. C., \& Santos-Buelga, C. (1995). Proanthocyanidins in skins from different grape varieties. Zeitschrift Für Lebensmittel-Untersuchung Und -Forschung, 200(3), 221-224. http://dx.doi.org/ 10.1007/BF01190499.

EU-VITIS (The European Vitis Database). 2015. URL <http://www.eu-vitis.de> Accessed 06.05.2015.

Figueiredo-González, M., Cancho-Grande, B., \& Simal-Gándara, J. (2013). Effects on colour and phenolic composition of sugar concentration processes in dried-onor dried-off-vine grapes and their aged or not natural sweet wines. Trends in Food Science and Technology, 31(1), 36-54. http://dx.doi.org/10.1016/ j.tifs 2013.02 .004

Figueiredo-González, M., Cancho-Grande, B., Simal-Gándara, J., Teixeira, N., Mateus, N., \& De Freitas, V. (2014). The phenolic chemistry and spectrochemistry of red sweet wine-making and oak-aging. Food Chemistry, 152, 522-530. http:// dx.doi.org/10.1016/j.foodchem.2013.12.018.
Figueiredo-González, M., Martínez-Carballo, E., Cancho-Grande, B., Santiago, J. L., Martínez, M. C., \& Simal-Gándara, J. (2012). Pattern recognition of three Vitis vinifera L. red grapes varieties based on anthocyanin and flavonol profiles, with correlations between their biosynthesis pathways. Food Chemistry, 130(1), 9-19. http://dx.doi.org/10.1016/j.foodchem.2011.06.006.

Figueiredo-González, M., Regueiro, J., Cancho-Grande, B., \& Simal-Gándara, J. (2014) Garnacha Tintorera-based sweet wines: Detailed phenolic composition by HPLC/DAD-ESI/MS analysis. Food Chemistry, 143, 282-292. http://dx.doi.org/ 10.1016/j.foodchem.2013.07.120.

Figueiredo-González, M., Simal-Gándara, J., Boso, S., Martínez, M. C., Santiago, J. L., \& Cancho-Grande, B. (2012). Anthocyanins and flavonols berries from Vitis vinifera L. cv. Brancellao separately collected from two different positions within the cluster. Food Chemistry, 135(1), 47-56. http://dx.doi.org/10.1016/j.foodchem. 2012.04.054.

Fraige, K., Pereira-Filho, E. R., \& Carrilho, E. (2014). Fingerprinting of anthocyanins from grapes produced in Brazil using HPLC-DAD-MS and exploratory analysis by principal component analysis. Food Chemistry, 145, 395-403. http:// dx.doi.org/10.1016/j.foodchem.2013.08.066.

Gómez Gallego, M. A., Gómez García-Carpintero, E., Sánchez-Palomo, E., HermosínGutiérrez, I., \& González Viñas, M. A. (2011). Study of phenolic composition and sensory properties of red grape varieties in danger of extinction from the Spanish region of Castilla-La Mancha. European Food Research and Technology, 234(2), 295-303. http://dx.doi.org/10.1007/s00217-011-1636-0.

González-Manzano, S., Rivas-Gonzalo, J. C., \& Santos-Buelga, C. (2004). Extraction of flavan-3-ols from grape seed and skin into wine using simulated maceration. Analytica Chimica Acta, 513(1), 283-289. http://dx.doi.org/10.1016/j.aca.2003. 10.019 .

He, F., Mu, L., Yan, G.-L., Liang, N.-N., Pan, Q.-H., Wang, J., et al. (2010). Biosynthesis of anthocyanins and their regulation in colored grapes. Molecules, 15(12), 9057-9091. http://dx.doi.org/10.3390/molecules15129057.

IPMA (Instituto Português do Mar e da Atmosfera)/PORDATA (Base de Dados Portugal Contemporâneo). 2015. URL <http://www.pordata.pt> Accessed 06.05.2015.

Ivanova, V., Stefova, M., Vojnoski, B., Dörnyei, Á., Márk, L., Dimovska, V., et al. (2011) Identification of polyphenolic compounds in red and white grape varieties grown in R. Macedonia and changes of their content during ripening. Food Research International, 44(9), 2851-2860. http://dx.doi.org/10.1016/j.foodres. 2011.06.046.

Jackson, R. S. (2008). Grapevine structure and function. In Wine science: Principles and applications, pp. 85). San Diego: Academic Press.

Kobayashi, S., Goto-Yamamoto, N., \& Hirochika, H. (2004). Retrotransposon-induced mutations in grape skin color. Science, 304(5673), 982. http://dx.doi.org/ 10.1126/science. 1095011.

Kuhn, N., Guan, L., Dai, Z. W., Wu, B.-H., Lauvergeat, V., Gomès, E., et al. (2014). Berry ripening: Recently heard through the grapevine. Journal of Experimental Botany, 65(16), 4543-4559. http://dx.doi.org/10.1093/jxb/ert395.

Liang, Z., Owens, C. L., Zhong, G.-Y., \& Cheng, L. (2011). Polyphenolic profiles detected in the ripe berries of Vitis vinifera germplasm. Food Chemistry, 129(3) 940-950. http://dx.doi.org/10.1016/j.foodchem.2011.05.050.

Martín, J. P., Borrego, J., Cabello, F., \& Ortiz, J. M. (2003). Characterization of Spanish grapevine cultivar diversity using sequence-tagged microsatellite site markers. Genome, 46(1), 10-18. http://dx.doi.org/10.1139/g02-098.

Martín, J. P., Santiago, J. L., Pinto-Carnide, O., Leal, F., Martinez, M. D., \& Ortiz, J. M. (2006). Determination of relationships among autochthonous grapevine varieties (Vitis vinifera L.) in the northwest of the Iberian peninsula by using microsatellite markers. Genetic Resources and Crop Evolution, 53(6), 1255-1261. http://dx.doi.org/10.1007/s10722-005-5679-6.

Mattivi, F., Guzzon, R., Vrhovsek, U., Stefanini, M., \& Velasco, R. (2006). Metabolite profiling of grape: Flavonols and anthocyanins. Journal of Agricultural and Food Chemistry, 54(20), 7692-7702. http://dx.doi.org/10.1021/jf061538c.

Merdinoglu, D., Butterlin, G., Bevilacqua, L., Chiquet, V., Adam-Blondon, A.-F., \& Decroocq, S. (2005). Development and characterization of a large set of microsatellite markers in grapevine (Vitis vinifera L.) suitable for multiplex PCR. Molecular Breeding, 15(4), 349-366. http://dx.doi.org/10.1007/s11032-0047651-0.

Mulinacci, N., Santamaria, A. R., Giaccherini, C., Innocenti, M., Valletta, A., Ciolfi, G., et al. (2008). Anthocyanins and flavan-3-ols from grapes and wines of Vitis vinifera cv. Cesanese d'Affile. Natural Product Research, 22(12), 1033-1039. http://dx.doi.org/10.1080/14786410802133845.

Núñez, V., Monagas, M., Gomez-Cordovés, M. C., \& Bartolomé, B. (2004). Vitis vinifera L. cv. Graciano grapes characterized by its anthocyanin profile. Postharvest Biology and Technology, 31(1), 69-79. http://dx.doi.org/10.1016/S09255214(03)00140-6.

OIV. (2009). 2nde Édition de la Liste des Descripteurs OIV pour les Variétés et Espèces de Vitis (2nd ed.). Paris, France: Ed. OIV.

Pinto-Carnide, O., Martin, J. P., Leal, F., Castro, I., Guedes-Pinto, H., \& Ortiz, J. M. (2003). Characterization of grapevine (Vitis vinifera L.) cultivars from northern Portugal using RADP and microsatellite markers. Vitis, 42(1), 23-25.

Quijada-Morín, N., Regueiro, J., Simal-Gándara, J., Tomás, E., Rivas-Gonzalo, J. C., \& Escribano-Bailón, M. T. (2012). Relationship between the sensory-determined astringency and the flavanolic composition of red wines. Journal of Agricultural and Food Chemistry, 60(50), 12355-12361. http://dx.doi.org/ $10.1021 / \mathrm{jf} 3044346$. 
Santos-Buelga, C., Francia-Aricha, E. M., \& Escribano-Bailón, M. T. (1995) Comparative flavan-3-ol composition of seeds from different grape varieties. Food Chemistry, 53(2), 197-201. http://dx.doi.org/10.1016/03088146(95)90788-9.

Sefc, K. M. Regner, F. Turetschek, E. Glossl, J, \& Steinkellner, H. (1999). Identification of microsatellite sequences in Vitis riparia and their applicability for genotyping of different Vitis species. Genome, 42(3), 367-373.

Teixeira, A., Eiras-Dias, J., Castellarin, S. D., \& Gerós, H. (2013). Berry phenolics of grapevine under challenging environments. International Journal of Molecular Sciences, 14(9), 18711-18739. http://dx.doi.org/10.3390/ijms140918711.

This, P., Lacombe, T., Cadle-Davidson, M., \& Owens, C. L. (2007). Wine grape (Vitis vinifera L.) color associates with allelic variation in the domestication gene
VvmybA1. Theoretical and Applied Genetics, 114(4), 723-730. http://dx.doi.org/ 10.1007/s00122-006-0472-2.

Veloso, M. M., Almandanim, M. C., Baleiras-Couto, M., Pereira, H. S., Carneiro, L. C., Fevereiro, P., et al. (2010). Microsatellite database of grapevine (Vitis vinifera L.) cultivars used for wine production in Portugal. Ciência E Técnica Vitivinícola, 25(2), 53-61.

Zheng, Y., Li, J. H., Xin, H. P., Wang, N., Guan, L., Wu, B. H., et al. (2013). Anthocyanin profile and gene expression in berry skin of two red Vitis vinifera grape cultivars that are sunlight dependent versus sunlight independent. Australian Journal of Grape and Wine Research, 19(2), 238-248. http://dx.doi.org/10.1111/ ajgw.12023. 